\title{
PHOTOSYNTHETIC CHARACTERISTICS OF SUMMER MAIZE UNDER DIFFERENT PLANTING PATTERNS AND THE RESPONSES TO NITROGEN APPLICATION OF PREVIOUS CROP
}

\author{
CARACTERÍSTICAS FOTOSSINTÉTICAS DO MILHO VERÃO SOB DIFERENTES \\ PADRÕES DE PLANTIO E AS RESPOSTAS À APLICAÇÃO DE NITROGÊNIO DA \\ CULTURA ANTERIOR
}

\author{
X. B. ZHOU ${ }^{1}$; P. J. SHEN ${ }^{1}$; Y. X. ZHAO ${ }^{1}$; D. H. JIANG ${ }^{1}$; J. H. HUANG ${ }^{1}$ \\ Guangxi Colleges and Universities Key Laboratory of Crop Cultivation and Farming System, Agricultural College of Guangxi \\ University, Nanning 530004, China. *Corresponding author’s e-mail: xunbozhou@ gmail.com
}

\begin{abstract}
Maize (Zea mays L.) is one of the most important grain crops in the North China Plain. Management practices affect the photosynthetic characteristics and the production of summer maize. This twoyear (2014-2015) study examined the effects of different planting patterns and the application of nitrogen to previous winter wheat (Triticum aestivum L.) on the photosynthetic characteristics, yield and radiation use efficiency (RUE) of summer maize. Field experiments used a two-factor split-plot design with three replicates at Taian, Shandong Province, China $\left(36^{\circ} 09^{\prime} \mathrm{N}, 117^{\circ} 09^{\prime} \mathrm{E}\right)$. The experiments involved two planting patterns (ridge planting, RP; and uniform row planting, UR) and two nitrogen application levels of previous winter wheat $\left(\mathrm{N} 1,112.50 \mathrm{~kg} \mathrm{ha}^{-1} ; \mathrm{N} 2,225.00 \mathrm{~kg} \mathrm{ha}^{-1}\right)$. The results indicated that the application of nitrogen on previous crop and ridge planting of the following crop had significant effects on the photosynthetic characteristics and yields of summer maize. Compared with UR, this study found that RP increased the chlorophyll content index (CCI), leaf area index (LAI), net photosynthetic rate (Pn), dry matter (DM), yield and grain RUE by $4.1 \%, 6.3 \%, 5.2 \%, 6.4 \%, 8.9 \%$ and $9.4 \%$, respectively. The CCI, LAI, Pn, yield, and grain RUE of $\mathrm{N} 2$ were $9.7 \%, 3.3 \%, 3.7 \%, 10.0 \%$ and $10.1 \%$ higher than those of $\mathrm{N} 1$, respectively. RP combined with the application of nitrogen on previous crop of winter wheat could increase the CCI, LAI, Pn, DM, ultimately increasing the grain yield and RUE of the following summer's maize. It was concluded that previous crop nitrogen application and RP pattern treatment resulted in optimal cropping conditions for the North China plain.
\end{abstract}

KEYWORDS: Zea mays L. Ridge plantin. Nitrogen level. Photosynthetic rate. Leaf area index. Yield.

\section{INTRODUCTION}

Maize (Zea mays L.) has become an important pillar of agricultural development in China and is the third primary crop. Currently, there are many kinds of planting patterns that are used to attain high grain yields in maize production. The maize planting patterns used in China include flat planting, ridge planting, and furrow planting (WU et al., 2017). Planting pattern affects the population structure of crops, in addition to physiological characteristics, such as light utilization (ZHANG et al., 2017). This study hypothesizes that ridge planting is superior to conventional flat planting, which has been widely promoted and has been significantly improved in many ways, including conserving water, improving fertilizer use efficiency, and increasing grain yield (MAJEED et al., 2015). Zhang et al. (2012) and Yao (2015) indicate that ridge planting can affect enzyme activities and microbial functional groups, increase photosynthetic parameters, gas exchange rates, root absorption, and reduce water consumption. In addition, the canopy structure, net photosynthetic rate, stomatal conductance, transpiration rate, and the relative content of chlorophyll in maize leaves is also increased under ridge planting (TAO et al., 2013).

Some studies have shown that the application of nitrogen fertilizers positively influences photosynthetic characteristics and maize grain yield (VOS et al., 2005; JAVEED et al., 2013). The application of nitrogen fertilizer can result in considerable increases in maize yields and profitability (JAMA et al., 2017); however, the application of excess nitrogen can lead to environmental problems, particularly for soil and groundwater quality (LI et al., 2016). The key to addressing this problem is to apply nitrogen rationally, taking into account the nitrogen applied to the previous crop. The maize yield of tillage systems that combine fertilizer applications is significantly higher than that of conventional systems (TUECHE; HAUSER, 2011). Little 
attention has been given to how planting patterns combined with nitrogen application of previous crops affect summer maize. The objective of this study was to evaluate the combined effects of ridge planting and the application of nitrogen on previous winter wheat (Triticum aestivum) on the photosynthetic characteristics and grain yield of summer maize.

\section{MATERIAL AND METHODS}

A field experiment was conducted at the Agronomy Experimental Station of Shandong Agricultural University, Taian, Shandong Province, China $\left(36^{\circ} 09^{\prime} \mathrm{N}, 117^{\circ} 09^{\prime} \mathrm{E}\right)$. The winter wheatsummer maize rotation is an important cropping system in the North China Plain. In the experimental
ZHOU, X. B. et al.

area, winter wheat (var. Jimai 22) was cultivated before the planting of summer maize (var. Zhengdan 958 ) in 2014 and 2015. Summer maize was sowed on June 152014 and June 15 2015, respectively, 10 days after winter wheat harvested. The planting density was 62500 plants $\mathrm{ha}^{-1}$ and harvested on September 272014 and September 30 2015. This study utilized a two-factor split-plot design, with two planting patterns (ridge planting, RP; and uniform row planting, UR) for the main plot, and two nitrogen application levels on previous winter wheat $\left(\mathrm{N} 1,112.5 \mathrm{~kg} \mathrm{ha}^{-1} ; \mathrm{N} 2,225.0 \mathrm{~kg} \mathrm{ha}^{-1}\right)$ for the sub-plot (Figure 1). The summer maize field experiment had three replications, and no nitrogen was applied for field plots. Each plot was $4 \times 4 \mathrm{~m}$ in size.

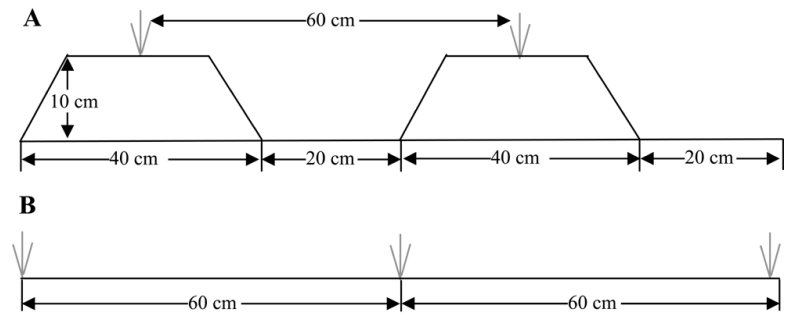

Figure 1. The summer maize ridge planting (A) and uniform row planting (B).

The study site characterizes the main summer maize growth area of North China with a warm-temperate monsoon climate. During the summer maize growing season, precipitation values were $372.5 \mathrm{~mm}$ and $282.6 \mathrm{~mm}$ for 2014 and 2015 , respectively (Table 1), and the annual temperature mean was $25.0^{\circ} \mathrm{C}$ (1971-2015). The physical and chemical properties of the experimental site soil layer at a depth from $0 \mathrm{~cm}$ to $20 \mathrm{~cm}$ were tested before planting the maize (Table 2).

Table 1. Monthly rainfall (mm) in the 2014 and 2015 summer maize growing season.

\begin{tabular}{|c|c|c|c|c|c|}
\hline Month & June (Sowing) & July & August & September (Harvest) & Total \\
\hline 2014 & 65.0 & 135.2 & 35.3 & 137.0 & 372.5 \\
\hline 2015 & 74.7 & 74.2 & 120.7 & 13.0 & 282.6 \\
\hline
\end{tabular}

Table 2. The soil physical and chemical properties of the experimental field.

\begin{tabular}{cllllll}
\hline $\mathrm{pH}$ & $\begin{array}{l}\text { Total N } \\
\left(\mathrm{mg} \mathrm{kg}^{-1}\right)\end{array}$ & $\begin{array}{l}\text { Available P } \\
\left(\mathrm{mg} \mathrm{kg}^{-1}\right)\end{array}$ & $\begin{array}{l}\text { Available K } \\
\left(\mathrm{mg} \mathrm{kg}^{-1}\right)\end{array}$ & $\begin{array}{l}\text { Soil bulk density } \\
\left(\mathrm{g} \mathrm{cm}^{-3}\right)\end{array}$ & $\begin{array}{l}\text { Soil organic matter } \\
\left(\mathrm{g} \mathrm{kg}^{-1}\right)\end{array}$ & $\begin{array}{l}\text { Field capacity } \\
(\mathrm{V} \%)\end{array}$ \\
\hline 6.9 & 123.2 & 40.6 & 124.5 & 1.50 & 18.9 & 38.6 \\
\hline
\end{tabular}

For vegetative growth stages: V6 (sixth leaf), reproductive development stages: R0 (silking stage), R2 (blister stage), R3 (milk stage), and R4 (dough stage), the chlorophyll content index (CCI) and the net photosynthetic rate $(\mathrm{Pn})$ of the ear leaf, the dry matter (DM) and the leaf area index (LAI) were measured (RITCHIE et al., 1986).

The leaf, stem, and ear samples were separated and placed in a drying oven at $105^{\circ} \mathrm{C}$ for $30 \mathrm{~min}$ and then dried at $80^{\circ} \mathrm{C}$ until they reached a constant weight. The following equations were used to calculate the leaf area and radiation use efficiency (RUE):

$$
\text { Leaf area }=\text { leaf length } \times \text { leaf width } \times 0.83
$$

where leaf length is the distance between the leaf pillow and the leaf tip, and leaf width is the widest part of the leaf.

$$
\operatorname{RUE}(\%)=\Delta \mathrm{W} \times \mathrm{H} / \Sigma \mathrm{S} \times 100 \%
$$

In this equation, $\Delta \mathrm{W}$ is grain yield $\left(\mathrm{T} \mathrm{ha}^{-1}\right)$ of summer maize, $\mathrm{H}$ is the rate of product heat (grain is $16.5 \mathrm{MJ} \mathrm{kg}^{-1}$; stem and leaf are $14.4 \mathrm{MJ} \mathrm{kg}^{-}$ 
$\left.{ }^{1}\right)$, and $\Sigma \mathrm{S}$ is the total radiation $\left(1.95 \times 10^{7} \mathrm{MJ} \mathrm{ha}^{-1}\right.$ from 2014 and $2.21 \times 10^{7} \mathrm{MJ} \mathrm{ha}^{-1}$ from 2015).

$\mathrm{Pn}$ was measured using a LI-6400XT system (LI-COR Inc., Lincoln, USA), and CCI was measured with a Chlorophyll meter 200 (OptiSciences Inc., Tyngsboro, USA) from 09:0011:00.

All graphs were generated with SigmaPlot 10.0 (SPSS Inc., Chicago, USA). The trail data were analyzed via SAS 9.2, and the treatment means were compared using LSD $(P<0.05)$.

\section{RESULTS AND DISCUSSION}

\section{Chlorophyll content index (CCI)}

Figure 2 shows an increasing initial CCI trend, followed by a decreasing trend, and it indicates the turning CCI points of different treatments of R0 and R2 for 2014 and 2015, respectively. Compared with UR, the CCI of RP increased by $3.6 \%$ (2014) and $4.6 \%$ (2015). The CCI of summer maize with RP and UR decreased by $38.8 \%$ and $39.3 \%$ from R0 to R4 (2014) and $28.4 \%$ and $31.6 \%$ from R2 to R4 (2015), respectively. The CCI averages of RP and UR were 40.7 in 2014 and 39.1 in 2015, respectively, and the CCI of RP increased by $4.1 \%$ compared to that of UR. This finding illustrated that RP was beneficial to the improvement of CCI. According to the 2-year results, the average CCI of N1 and N2 was 37.4 and 42.4 (2014) and 38.0 and 41.7 (2015) during each growing season, respectively. The average CCI values of $\mathrm{N} 2$ were significantly higher than those of N1.

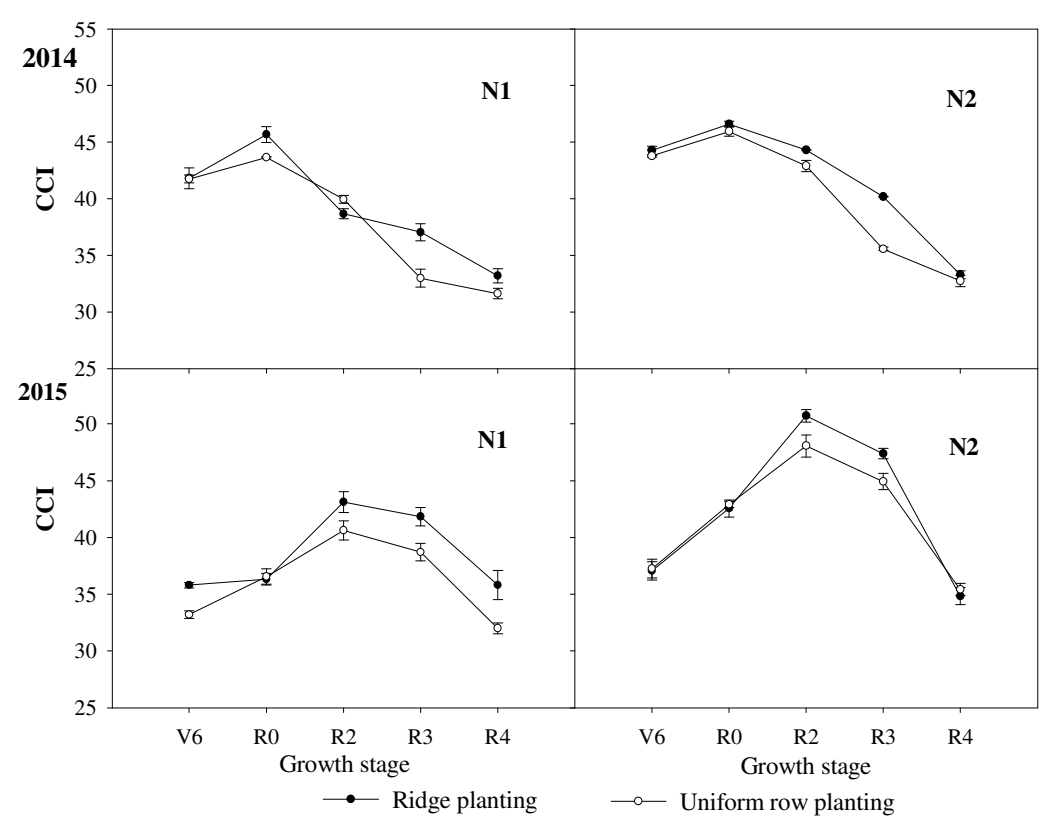

Figure 2. Effects of planting pattern and nitrogen on chlorophyll content index (CCI) of summer maize. N1 $\left(112.5 \mathrm{~kg} \mathrm{ha}^{-1}\right)$ and $\mathrm{N} 2\left(225.0 \mathrm{~kg} \mathrm{ha}^{-1}\right)$ were nitrogen content; bars were s.e.

\section{Leaf area index (LAI)}

With the growth of summer maize, the LAI of $\mathrm{RP}$ and UR reached the highest point at R2. The average LAI values of RP and UR were 5.35 and 3.32 , respectively, and the LAI of RP was $6.3 \%$ higher than that of UR over 2 years (Figure 3). The LAI descent ranges of RP and UR were $45.3 \%$ and $56.6 \%$ from R2 to R4, indicating that RP could significantly improve the LAI of summer maize and depress the decrease of late growth stages. In twoyear study, the ranking of the LAI average was N2 > $\mathrm{N} 1$, with specific values of 3.60 and 3.25 , respectively. For $\mathrm{N} 1$ and $\mathrm{N} 2$ treatments, the maximum change range of LAI variation was $5.7 \%$ and $6.9 \%$, respectively. The LAI of RP was $3.3 \%$ higher than that of UR under N2. This showed that the RP was beneficial to increasing LAI values for summer maize. 


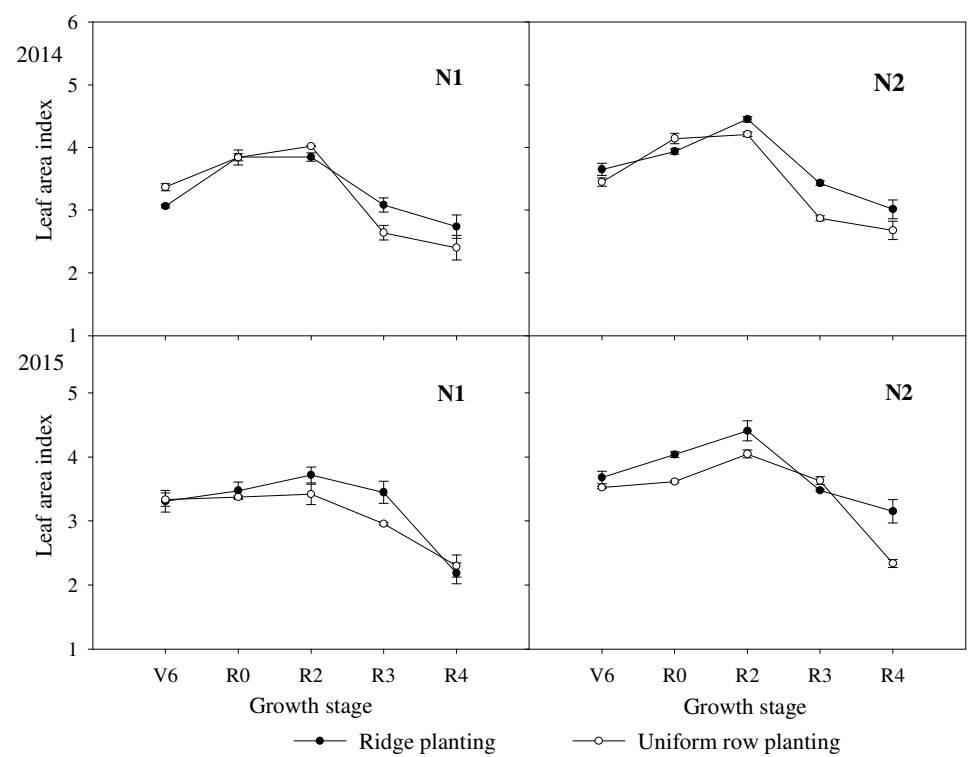

Figure 3. Effects of planting pattern and nitrogen amount on leaf area index of summer maize. N1 (112.5 kg $\left.\mathrm{ha}^{-1}\right)$ and N2 $\left(225.0 \mathrm{~kg} \mathrm{ha}^{-1}\right)$ were nitrogen content; bars were s.e.

\section{Photosynthetic rate (Pn)}

The different planting patterns and nitrogen fertilization influenced the Pn of the summer maize in 2014 and 2015 (Figure 4). The Pn mean decreased gradually with growth for two years, and the Pn values for V6, R0, R2, R3 and R4 were 41.7, 39.5, 34.0, 28.8 and $15.1 \mu \mathrm{mol} \mathrm{CO}_{2} \mathrm{~m}^{-2} \mathrm{~s}^{-1}$, respectively. The curve displayed that $\mathrm{Pn}$ decreased slowly at the early stages (V6-R2), and decreased rapidly in the late growth stages (R2-R4). Compared with UR, the Pn mean of the RP treatment from
2014 to 2015 increased by $5.2 \%$. Pn values across the whole growth period were characterized by a N2 $>$ N1 relationship, with specific Pn mean values for $\mathrm{N} 1$ and $\mathrm{N} 2$ of $32.5 \mu \mathrm{mol} \mathrm{CO} \mathrm{C}^{-2} \mathrm{~s}^{-1}$ (2014) and 35.2 rmol $\mathrm{CO}_{2} \mathrm{~m}^{-2} \mathrm{~s}^{-1}$ (2015), respectively. The $\mathrm{Pn}$ values of $\mathrm{N} 1$ and $\mathrm{N} 2$ at R4 decreased by $66.0 \%$ and $55.7 \%$ compared with $\mathrm{R} 2$, respectively. These results show that $\mathrm{N} 2$ could maintain a relatively high Pn and help to increase the yield of summer maize. The Pn of N2 was $3.7 \%$ higher than that of N1.

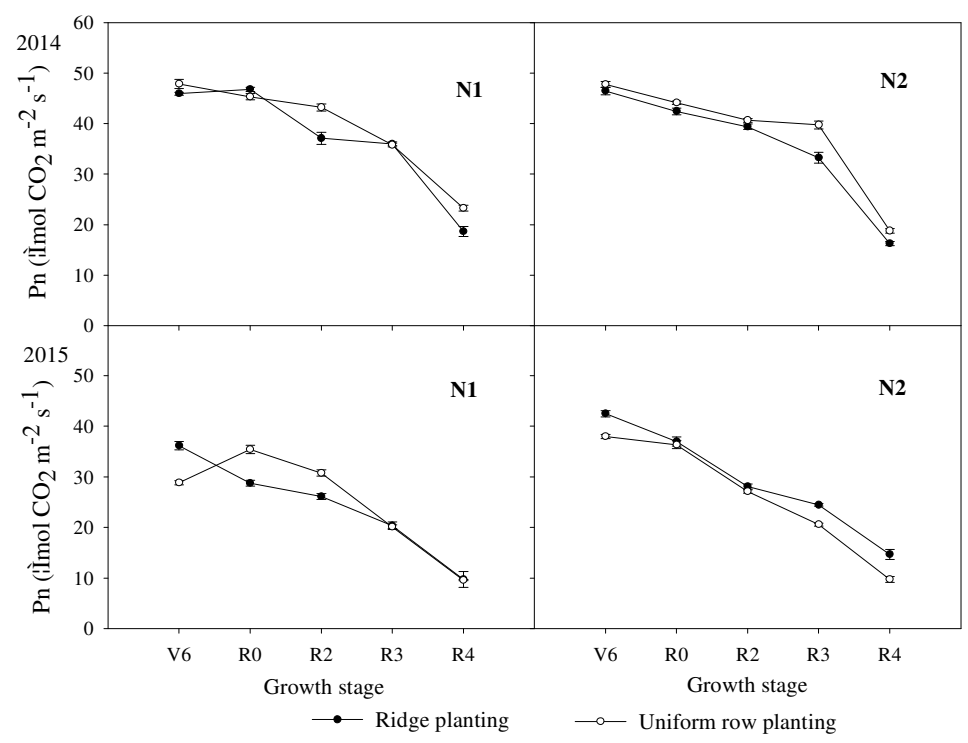

Figure 4. Effects of planting patterns and nitrogen amount on net photosynthetic rate (Pn) of summer maize. $\mathrm{N} 1\left(112.5 \mathrm{~kg} \mathrm{ha}^{-1}\right)$ and N2 (225.0 kg ha $\left.{ }^{-1}\right)$ were nitrogen content; bars were s.e. 


\section{Dry matter (DM)}

DM showed an increasing trend with growth (Figure 5). The DM of RP was significantly higher than that of UR for R2, R3 and R4, and the trend was consistent across 2 years. During the 2015 growing season, the DM mean of $\mathrm{N} 2$ was $5.8 \%$ greater than that of $\mathrm{N} 1$, and there was no significant difference $(P>0.05)$. From 2014 to 2015 , the DM of N2 was significantly higher than that of N1 $(P<$ $0.05)$. DM means for RP and UR were 9810 and $9322 \mathrm{~kg} \mathrm{ha}^{-1}$ (2014), and 8444 and $7603 \mathrm{~kg} \mathrm{ha}^{-1}$ (2015), respectively. The DM of RP was significant higher than that of UR.

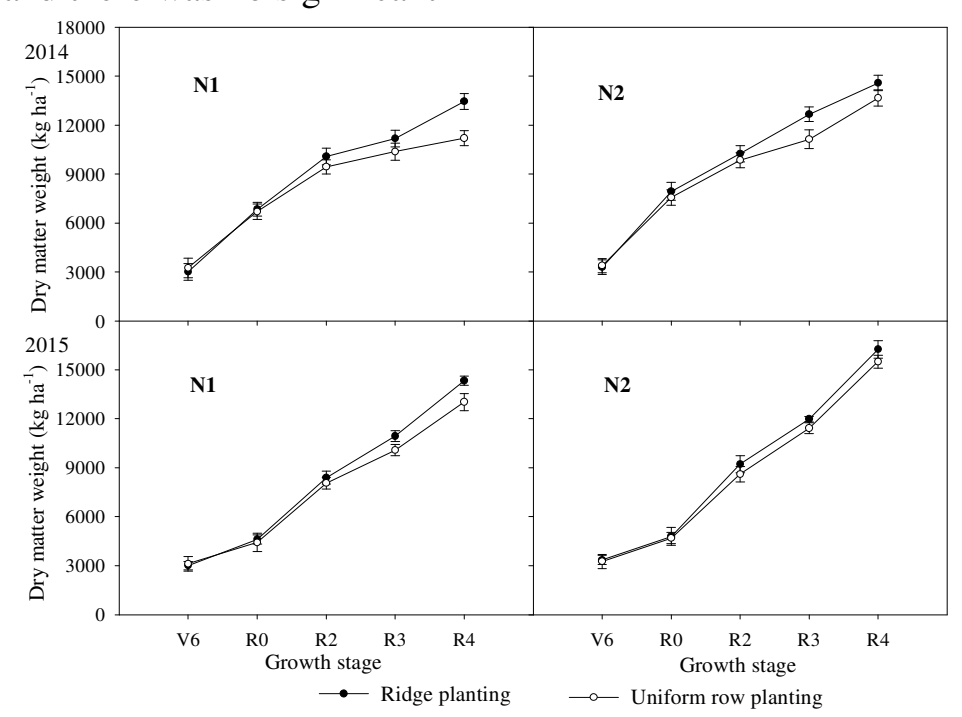

Figure 5. Effects of planting patterns and nitrogen amount on dry matter weight of summer maize. N1 (112.5 $\left.\mathrm{kg} \mathrm{ha}^{-1}\right)$ and N2 (225.0 $\left.\mathrm{kg} \mathrm{ha}^{-1}\right)$ were nitrogen content; bars were s.e.

\section{Yield and radiation use efficiency (RUE)}

In 2014 growth season, biomass yield and biomass RUE of UR (N1) and RP (N2) were significantly higher than that of RP (N1), grain yield and grain RUE of RP (N2) were significantly higher than that of UR $(\mathrm{N} 1)(P<0.05)$; in 2015 growth season, biomass yield and biomass RUE were no significantly between different treatments $(P>$ $0.05)$, grain yield and grain RUE of RP (N2) were significantly higher than those of other treatments $(P<0.05)$. Under N1, means of tow growth seasons of biomass yield, grain yield, biomass RUE and grain RUE were $1.76 \mathrm{~T} \mathrm{ha}^{-1}, 0.95 \mathrm{~T} \mathrm{ha}^{-1}, 1.31 \%$, $0.76 \%(\mathrm{RP})$ and $1.89 \mathrm{~T} \mathrm{ha}^{-1}, 0.85 \mathrm{~T} \mathrm{ha}^{-1}, 1.40 \%$,
$0.68 \%$ (UR); under N2, means of tow growth seasons of biomass yield, grain yield, biomass RUE and grain RUE were $1.88 \mathrm{~T} \mathrm{ha}^{-1}, 1.02 \mathrm{~T} \mathrm{ha}^{-1}, 1.41 \%$, $0.82 \%(\mathrm{RP})$ and $1.84 \mathrm{~T} \mathrm{ha}^{-1}, 0.96 \mathrm{~T} \mathrm{ha}^{-1}, 1.38 \%$, $0.76 \%$ (UR) (Table 3). These results indicated that nitrogen fertilization of previous crop, yield of the following maize were increased under the same planting pattern; yield of RP was $11.7 \%$ (N1) and $6.3 \%$ (N2) higher than those of UR. The results showed that biomass yield and RUE there were significantly interaction effect between application nitrogen in previous crop and following summer maize planting pattern $(P<0.05)$.

Table 3. Effects of planting patterns (PP) and nitrogen amount on yield and radiation use efficiency (RUE) of summer maize.

\begin{tabular}{llllllllll}
\hline \multicolumn{2}{l}{ Treatments } & \multicolumn{2}{c}{ Biomass yield $\left(\mathrm{T} \mathrm{ha}^{-1}\right)$} & \multicolumn{2}{c}{ Grain yield $\left(\mathrm{T} \mathrm{ha}^{-1}\right)$} & \multicolumn{2}{c}{ Biomass RUE $(\%)$} & \multicolumn{2}{c}{ Grain RUE (\%) } \\
\cline { 3 - 10 } & & 2014 & 2015 & 2014 & 2015 & 2014 & 2015 & 2014 & 2015 \\
\hline $\mathrm{N} 1$ & $\mathrm{RP}$ & $1.63 \mathrm{~b}$ & $1.88 \mathrm{a}$ & $0.98 \mathrm{ab}$ & $0.91 \mathrm{~b}$ & $1.31 \mathrm{~b}$ & $1.31 \mathrm{a}$ & $0.83 \mathrm{ab}$ & $0.68 \mathrm{~b}$ \\
& $\mathrm{UR}$ & $1.85 \mathrm{a}$ & $1.93 \mathrm{a}$ & $0.84 \mathrm{~b}$ & $0.86 \mathrm{~b}$ & $1.46 \mathrm{a}$ & $1.34 \mathrm{a}$ & $0.71 \mathrm{~b}$ & $0.64 \mathrm{~b}$ \\
$\mathrm{~N} 2$ & $\mathrm{RP}$ & $1.87 \mathrm{a}$ & $1.89 \mathrm{a}$ & $1.01 \mathrm{a}$ & $1.03 \mathrm{a}$ & $1.49 \mathrm{a}$ & $1.33 \mathrm{a}$ & $0.86 \mathrm{a}$ & $0.77 \mathrm{a}$ \\
& $\mathrm{UR}$ & $1.76 \mathrm{ab}$ & $1.92 \mathrm{a}$ & $0.98 \mathrm{ab}$ & $0.93 \mathrm{~b}$ & $1.41 \mathrm{ab}$ & $1.34 \mathrm{a}$ & $0.83 \mathrm{ab}$ & $0.69 \mathrm{~b}$ \\
\hline \multirow{2}{*}{$\mathrm{P}$ value } & $\mathrm{N}$ & 0.7195 & 0.8125 & 0.3507 & 0.1640 & 0.0940 & 0.6561 & 0.1381 & 0.0042 \\
& $\mathrm{PP}$ & 0.8101 & 0.1209 & 0.3482 & 0.2085 & 0.3775 & 0.3342 & 0.1372 & 0.0134 \\
& $\mathrm{~N} \times \mathrm{PP}$ & 0.0205 & 0.5990 & 0.2060 & 0.2837 & 0.0241 & 0.4693 & 0.5261 & 0.2837 \\
\hline
\end{tabular}

$\mathrm{N} 1,112.5 \mathrm{~kg} \mathrm{ha}^{-1} ; \mathrm{N} 2,225.0 \mathrm{~kg} \mathrm{ha}^{-1} ; \mathrm{RP}$, ridge planting; UR, uniform row planting. Values followed by a different small letter within a column are significantly different at $5 \%$ probability level. 


\section{The correlation analysis between yield and photosynthetic factors}

The N, Pn, CCI, LAI and yield correlation analysis of summer maize for the 2-year results is shown in Table 4. There was significant positive correlation between N, Pn, CCI, and LAI with yield $(P<0.05)$; between Pn and CCI $(P<0.01)$. In addition, there was significant positive correlation among N, CCI, LAI, and yield $(P<0.05)$.

Table 4. The correlation analysis between yield and photosynthetic factors.

\begin{tabular}{llllll}
\hline \multicolumn{2}{l}{ Person correlation coefficients } & \multicolumn{3}{l}{} \\
\hline Variable & $\mathrm{N}$ & $\mathrm{Pn}$ & $\mathrm{CCI}$ & LAI & Yield \\
\hline $\mathrm{N}$ & 1.000 & $0.926^{* *}$ & $0.990^{* *}$ & $0.882^{*}$ & $0.988^{* *}$ \\
Pn & & 1.000 & $0.941^{* *}$ & 0.791 & $0.897^{* *}$ \\
$\mathrm{CCI}$ & & 1.000 & $0.913^{*}$ & $0.982^{* *}$ \\
LAI & & & 1.000 & $0.933^{* *}$ \\
Yield & & & & 1.000 \\
\hline
\end{tabular}

*, ** Correlation is significant at the 0.05 and 0.01 level, respectively.

Chlorophyll is an important pigment for photosynthesis (PENG et al., 2011). When the nitrogen level in previous crops was high, this study found that the CCI of maize leaves was also high, which indicated that CCI was strongly influenced by previous crop nitrogen levels. Other studies observed similar results (CLEVERS; KOOISTRA, 2012; SCHLEMMER et al., 2013). Leaves are the material carrier of intercepted light energy, and leaf size in maize is responsive to nitrogen supply and had a close relationship with photosynthetic rate. LAI is also one of the main physiological determinants of crop yield (HAMZEI; SOLTANI, 2012). The results of this study indicated that the relationship for the LAI and Pn averages was N2 > $\mathrm{N} 1$ and that N2 had advantage for increasing LAI, maintaining a relatively high $\mathrm{Pn}$ and increasing the yield of summer maize. In general, the increase of previous crop nitrogen content combined with using RP pattern for the following maize crops could enhance CCI and increase both Pn and grain yield.

RP has been widely used for wheat, maize, rice, and soybean crops, with varying increases of yield (SONG et al., 2013). REN et al. (2016) illustrates that RP is conducive to improved photosynthetic characteristics, contribute to photoassimilate accumulation and enhance maize productivity (JIANG et al., 2016). HASSAN et al. (2005) observe that there are increases of $30 \%$ in the grain yield of RP compared to flat planting pattern. This study demonstrated that previous winter wheat nitrogen levels significantly affected photosynthetic factors and yield of the following summer maize crop. The yields of different nitrogen contents can be significantly different owing to their differential impacts on growth and yield (HAMZEI; SOLTANI, 2012). The photosynthetic characteristics, grain RUE and yields of RP were higher than those of UR.

\section{CONCLUSIONS}

Previous crop nitrogen levels and following crop ridge planting pattern had a significant effect on the photosynthetic characteristics and yield of summer maize.

The use of RP pattern, combined with the application of nitrogen to previous winter wheat, could increase CCI, LAI, Pn, and DM, ultimately increasing the grain yield and RUE of the following summer maize crops.

This study demonstrated that the previous crop N2 (225.0 $\left.\mathrm{kg} \mathrm{ha}^{-1}\right)$ combined with following crop ridge planting pattern could be utilized for summer maize in the North China Plain.

\section{ACKNOWLEDGEMENTS}

The research was sponsored by the National Natural Science Foundation of China (31760354), Guangxi Natural Science Foundation (2017GXNSFAA198036). We would like to thanks Zhang Zhen for the work contribution.

RESUMO: O milho (Zea mays L.) é uma das culturas de grãos mais importantes da Planície do Norte da China. Práticas de manejo afetam as características fotossintéticas e a produção do milho verão. Este estudo de dois anos (2014-2015) examinou os efeitos de diferentes padrões de plantio e a aplicação de nitrogênio ao trigo de inverno anterior (Triticum aestivum L.) sobre as características fotossintéticas, produtividade e eficiência de uso de radiação (RUE) do milho verão. Experimentos de campo usaram um delineamento em 
parcelas subdivididas de dois fatores com três repetições em Taian, província de Shandong, China $\left(36^{\circ} 09^{\prime} \mathrm{N}\right.$, $117^{\circ} 09^{\prime} \mathrm{E}$ ). Os experimentos envolveram dois padrões de plantio (ridge planting, RP; e uniform row planting, UR) e dois níveis de aplicação de nitrogênio do trigo de inverno anterior (N1, 112,50 kg ha-1; N2, 225,00 kg ha-1). Os resultados indicaram que a aplicação de nitrogênio na cultura anterior e no plantio RP da cultura seguinte teve efeitos significativos nas características fotossintéticas e na produtividade do milho verão. Comparado com o plantio UR, este estudo concluiu que RP aumentou o índice de conteúdo de clorofila (CCI), índice de área foliar (LAI), taxa fotossintética líquida (Pn), matéria seca (DM), produtividade e RUE de grãos em $4,1 \%, 6,4 \%, 5,2 \%, 6,4 \%, 8,9 \%$ e $9,4 \%$, respectivamente. Os valores de CCI, LAI, Pn, produtividade e RUE de $\mathrm{N} 2$ foram $9,7 \%, 3,3 \%, 3,7 \%, 10,0 \%$ e 10,1\% superiores aos de N1, respectivamente. RP combinada com a aplicação de nitrogênio na safra anterior de trigo de inverno poderia aumentar os valores de CCI, LAI, Pn, DM, aumentando o rendimento de grãos e RUE do milho do verão seguinte. Concluiu-se que a aplicação prévia de nitrogênio na colheita e o tratamento com padrão RP resultaram em condições ótimas de cultivo para a planície do norte da China.

PALAVRAS-CHAVE: Zea mays L . Ridge planting. Nível de nitrogênio. Taxa fotossintética. Índice de área foliar. Produção.

\section{REFERENCES}

CLEVERS, J. G. P. W.; KOOISTRA, L. Using hyperspectral remote sensing data for retrieving canopy chlorophyll and nitrogen content. Journal of Selected Topics in Applied Earth Observations and Remote Sensing, v. 5, p. 574-583, 2012. https://doi.org/10.1109/JSTARS.2011.2176468

HAMZEI, J.; SOLTANI, J. Deficit irrigation of rapeseed for water-saving: Effects on biomass accumulation, light interception and radiation use efficiency under different $\mathrm{N}$ rates. Agriculture Ecosystems and Environment, v. 155, p. 153-160, 2012. https://doi.org/10.1016/j.agee.2012.04.003

HASSAN, I.; HUSSAIN, Z; AKBAR, G. Effect of permanent raised beds on water productivity for irrigated maize-wheat cropping system. ROTH, E. C.; FISCHER, R. A.; MEISNER, C. A. Eds. Evaluation and Performance of Permanent Raised Bed Cropping Systems in Asia, Australia and Mexico. Pp. 59-65, 2005.

JAMA, B.; KIMANI, D.; HARAWA, R.; MAVUTHU, A. K.; SILESHI, G. W. Maize yield response, nitrogen use efficiency and financial returns to fertilizer on smallholder farms in southern Africa. Food Security, v. 9, p. 1-17, 2017. https://doi.org/10.1007/s12571-017-0674-2

JAVEED, H. M. R.; ZAMIR, M. S. I. Influence of tillage practices and poultry manure on grain physical properties and yield attributes of spring maize (Zea mays L.). Pakistan Journal of Agricultural Sciences, v. 50, p. 177-183, 2013.

JIANG, R.; LI X.; ZHOU, M.; LI., H. J.; ZHAO, Y.; YI, J.; CUI, L. L.; LI, M.; ZHANG, J. G.; QU, D. Plastic film mulching on soil water and maize (Zea mays L.) yield in a ridge cultivation system on Loess Plateau of China. Soil Science and Plant Nutrition, v. 62, p. 1-15, 2016. https://doi.org/10.1080/00380768.2015.1104642

LI, Y.; LIU, H.; HUANG, G.; ZHANG, R.; YANG, H. Nitrate nitrogen accumulation and leaching pattern at a winter wheat: summer maize cropping field in the North China Plain. Environmental Earth Sciences, v. 75, p. 118, 2016. https://doi.org/10.1007/s12665-015-4867-8

MAJEED, A.; MUHMOOD, A.; NIAZ, A.; JAVID, S.; AHMAD, Z. A.; SHAH, S. S. H.; SHAH, A. H. Bed planting of wheat (Triticum aestivum L.) improves nitrogen use efficiency and grain yield compared to flat planting. The Crop Journal, v. 3, p. 118-124, 2015. https://doi.org/10.1016/j.cj.2015.01.003

PENG, Y.; GITELSON, A. A.; KEYDAN, G.; RUNDQUIST, D. C.; MOSES, W. Remote estimation of gross primary production in maize and support for a new paradigm based on total crop chlorophyll content. Remote Sensing of Environment, 115, p. 978-989, 2011. https://doi.org/10.1016/j.rse.2010.12.001 
REN, B. Z.; DONG, S. T.; LIU, P.; ZHAO, B.; ZHANG, J. W. Ridge tillage improves plant growth and grain yield of waterlogged summer maize. Agricultural Water Management, v. 177, p. 392-399, 2016. https://doi.org/10.1016/j.agwat.2016.08.033

RITCHIE, S. W.; HANWAY, J. J.; BENSON, G. O. How a Corn Plant Develops. Special report no. 48, Iowa State University, Ames, Iowa. 1986.

SCHLEMMER, M.; GITELSON, A.; SCHEPERS, J.; FERGUSON, R.; PENG, Y.; SHANAHAN, J.; RUNDQUIST, D. Remote estimation of nitrogen and chlorophyll contents in maize at leaf and canopy levels. International Journal of Applied Earth Observation and Geoinformation, v. 25, p. 47-54, 2013. https://doi.org/10.1016/j.jag.2013.04.003

SONG, Z. W.; GUO, J. R.; ZHANG, Z. P.; KOU, T. J.; DENG, A. X.; ZHENG, C. Y.; REN, J.; ZHANG, W. J. Impacts of planting systems on soil moisture, soil temperature and corn yield in rainfed area of Northeast China. European Journal of Agronomy, v. 50, p. 66-74, 2013. https://doi.org/10.1016/j.eja.2013.05.008

TAO, Z. Q.; SUI, P.; CHEN, Y. Q.; LI, C.; NIE, Z. J.; YUAN, S. F.; SHI, J. G.; GAO, W. S. Subsoiling and ridge tillage alleviate the high temperature stress in spring maize in the North China Plain. Journal of Integrative Agriculture, v. 12, p. 2179-2188, 2013. https://doi.org/10.1016/S2095-3119(13)60347-0

TUECHE, J. R.; HAUSER, S. Maize (Zea mays L.) yield and soil physical properties as affected by the previous plantain cropping systems, tillage and nitrogen application. Soil and Tillage Research, v. 115-116, p. 88-93, 2011. https://doi.org/10.1016/j.still.2011.07.004

VOS, J.; VAN DER PUTTEN, P. E. L.; BIRCH, C. J. Effect of nitrogen supply on leaf appearance, leaf growth, leaf nitrogen economy and photosynthetic capacity in maize (Zea mays L.). Field Crops Research, v. 93, p. 64-73, 2005. https://doi.org/10.1016/j.fcr.2004.09.013

WU, Y.; HUANG, F. Y.; JIA, Z. K.; REN, X. L.; CAI, T. Response of soil water, temperature, and maize (Zea may L.) production to different plastic film mulching patterns in semi-arid areas of northwest China. Soil and Tillage Research, v. 166, p. 113-121, 2017. https://doi.org/10.1016/j.still.2016.10.012

YAO, Y. Z. Effects of ridge tillage on photosynthesis and root characters of rice. Chilean Journal of Agricultural Research, v. 75, p. 35-41, 2015. https://doi.org/10.4067/S0718-58392015000100005

ZHANG, X. L.; MA, L.; GILLIAMC, F. S.; WANG, Q.; LI, C. H. Effects of raised-bed planting for enhanced summer maize yield on rhizosphere soil microbial functional groups and enzyme activity in Henan Province, China. Field Crops Research, v. 130, p. 28-37, 2012. https://doi.org/10.1016/j.fcr.2012.02.008

ZHANG, Z.; MAO, X. M.; ZHONG, W. W.; FENG, Z. B.; ZHOU, X. B. Photosynthetic production of wheat under precision planting patterns in northern China. Bioscience Journal, v. 33, p. 1-9, 2017.

https://doi.org/10.14393/BJ-v33n1a2017-30328 